\title{
The Comparison of Some Motoric Characteristics of Hearing Impaired Individuals Sports Athletic and Gymnastic
}

\author{
Mehmet Ilkım, Betül Akyol* \\ Faculty of Sport Sciences, Inonu University, Malatya, Turkey
}

Copyright(C2018 by authors, all rights reserved. Authors agree that this article remains permanently open access under the terms of the Creative Commons Attribution License 4.0 International License

\begin{abstract}
The purpose of this study was to compare some motoric characteristics as a result of participating in physical activity education of hearing impaired individuals aged 12-14 doing athletics and gymnastics. The study consists of 30 athletes and 30 gymnastics students at the Hearing Impairments in Malatya Province. In the pre-test and post-test measures of the participants, flamingo balance test, flexibility, lower extremity reaction time test, quadriceps muscle strength, abdominal and back muscle strength, height, body weight, Body Mass Index (BMI) measurements were performed. Each participant was given physical activity training 3 days per week for 14 weeks. The flamingo balance test score of the both groups showed a decrease and reaction time of right and left side of athletes showed a decrease $(\mathrm{p}<0.05)$. When both groups were compared in terms of muscle strength, quadriceps femoris muscle strength was increased in athletic group ( $p$ $<0.05$ ), but not statistically significant differences were observed in gymnastic group regarding quadriceps femoris muscle strength $(p>0.05)$. As a result of the study, athletics is superior to gymnastic because it has been observed that athletics is more effective than gymnastics on balance, reaction time and muscle strength in individuals with hearing impaired.
\end{abstract}

Keywords Hearing Impaired, Athletics, Gymnastics

\section{Introduction}

In terms of physical fitness, hearing-impaired children among the disabled are not different from those who have no hearing problem. Some differences based on age and gender were observed in performance [15].

In early ages hearing impaired children can adapted to their peers. However, at later ages, it is seen that in skills related to balance and body coordination are not sufficient for providing gross and fine motor activity in hearing-impaired children.

People with hearing impairment are highly likely to have other such as tinnitus and balance disorders which cause in part as risk factors for falls and other accidental injury [6].

Childhood hearing impairment is a significant public health problem, which is associated with balance and motor deficits. Both the static and dynamic postural control are more important to execute movement. The development and providing of postural control are known to be a pre-requisite for the performance of skilled movement. Simple or complex gross and fine motor tasks have been shown to maintain his or her center of gravity. The development and providing of postural stability are a complex process that necessitates the involvement of multiple systems such as sensory system, central nervous system processing and co-ordination of motor output and the vestibular system [18].

Hearing-impaired children can be affected from daily life activity depending on their age, gender and hearing loss degree. The fact that their daily life is affected in hearing-impaired children because of loss of static and dynamic balance [7].

Social and emotional problems caused by hearing loss as well as walking and balance disorders affect negatively the quality of life [12].

When disabled individuals are lead to sports, it is seen the positive developments in their physical and physiological capacities [7]. Training program improves hearing impaired children's motor skills, balance and health related quality of lifestyle [16].

Sport helps to improve the ability with collaborate, develops the sense of sharing in the children with disabilities and sport provide to come together the children with disabilities and normal development. It also supports the muscular and nervous system, mental reactions and motor development [1].

Although it is known that the effect of sport on balance 
and motor properties in healthy individuals, there are not enough studies in the literature about the effects of sport on balance, muscle strength, flexibility and reaction time in hearing disabled people. In this study, it is aimed to compare the parameters of balance, reaction time, flexibility, muscle strength of hearing disabled people playing athletics and gymnastics.

\section{Materials and Methods}

\subsection{Study Group}

The study was carried out in hearing-impaired middle school in Malatya and 60 children (aged between 12 and 14 years, including 30 athletics, 30 gymnastic hearing-impaired children). Children participating in the study hearing loss is in the range of $90 \mathrm{~dB}-110 \mathrm{~dB}$. They use hearing aids. Participants pre-test and post-test measures included. The pre-treatment and post-treatment parameters included flamingo balance test, flexibility, lower extremity reaction time, quadriceps muscle strength, abdominal and back muscle strength, height, body weight, Body Mass Index (BMI) were evaluated between the groups, 14 weeks, 3 days a week; short outlets, double-step bounces, run-off bounces, straight-reverse bounces, headstand bounces, forward-back bridges, drop in sand ponds and running were done from participants. The running activity was done in 1-5 weeks $30 \mathrm{~m}, 5-10$ weeks $50 \mathrm{~m}, 10-14$ weeks $100 \mathrm{~m}$.

\subsection{Height, Body Weight Measurement}

Height was measured with the height scale on the bascule with a sensity level $0.01 \mathrm{~cm}$. Body weight was measured with shorts by the bascule with $0.01 \mathrm{~kg}$ sensitivity [5].

\subsection{BMI}

BMI was assessed using the formula: $\left(\mathrm{BMI}=(\mathrm{kg}) / \mathrm{m}^{2}\right)$. Body mass index (BMI) is a measure of body subcutenal tissue based on height and weight that applies to children with hearing-impaired [22].

\subsection{Reaction Time Measure}

Reaction time measure was made with a "Reaction Time Hubbard-Hap" mark reaction measurement device. Once the appropriate conditions were ensured and necessary information was given the children with hearing impaired the, he or she was asked to stand in the sitting position for the right and left foot reaction. The reaction measure device was placed in front of the feet and the visual test was measured and the data were recorded. Participants were tested 3 times and the best of average point was recorded.

\subsection{Flamingo Balance Test}

The Flamingo Balance Test was used to determine the static balances of the participants. The test was made on a metal beam consists from $50 \mathrm{~cm}$ long, $4 \mathrm{~cm}$ high and $3 \mathrm{~cm}$ wide. The beam is placed on two legs, $15 \mathrm{~cm}$ long and $2 \mathrm{~cm}$ wide, so as not to move. Flamingo Balance Test was done by trying to keep the balance as long as possible with the foot preferred by the participation. The participant twisted his free leg and held it with his hand on the same side. He used the other arm to balance. The number of trials of participants who succeeded in maintaining the balance for 1 minute was calculated and measured [10].

\subsection{Flexibility (Sit and Reach Test-OUT)}

The sit and reach test was used to evaluate the flexibility of the comparison groups. The over of a table measuring 32 $\mathrm{cm}$ in height and $35 \mathrm{~cm}$ in length was measured. Comparison groups sit around, stretches the legs and soles of the feet as lean feet on the table. Then stretch as far as possible from the torso (waist and hip), forward on the table, without bending the knees. The extreme point at which the fingers extend is measured in $\mathrm{cm}$. Athletics and gymnastics groups repeated this three times and the best grade achieved was recorded [10].

\subsection{Muscle Strength Measurement}

As part of the muscle test, we evaluated quadriceps femoris muscles, back extensors, abdominal muscles. Muscle testing was conducted with Dr. Robert W. Lovett's [14]. manual muscle testing method. This test comprises the following categories: Normal (5): muscle completes the range of motion with maximum resistance against gravity. Good (4): muscle completes its normal range of motion with resistance less than maximum resistance against gravity. Fair (3): muscle completes its normal range of motion against gravity. Poor (2): muscle completes its normal range of motion in a position with gravity eliminated. Trace (1): palpable contraction before disclosure of motion in the joint. Total paralysis (0): No muscle contraction.

\subsection{Data Analyses}

Data obtained in the study were analysed using IBM-SPSS Statistics 22.0 software. Data were summarized by mean \pm standard deviation. The appropriateness of the data to the normal distribution was assessed with Kolmogorov-Smirnov test while the homogeneity control of variances was assessed with Levene test. To analyse the data, we used the t test for independent samples between the groups; to compare the groups, we also used the t-test for dependent samples. We used IBM SPSS Statistics 22.0 for Windows software package for analyses. $\mathrm{p}<0.05$ was considered statistically 
significant.

\section{Results}

A total of 60 children with hearing-impaired participated in this study. The mean age of athletics group was $12.83 \pm 1.64$ and gymnastics group was $12.38 \pm 1.49$ years (range 12-14 years). The mean age, weight, height and BMI of the groups are shown in Table 1 as mean and standard deviations. There was no statistically significant difference between the groups of age ( $p>0.05)$ There was statistically significant difference between the groups of weight, height and BMI $(\mathrm{p}<0.001)$.

Table 2 presents comparison before and after the sport the values of flamingo balance test, sit and reach test, reaction time between two groups. In calculating the scores of physical activity training, there was a decrease in flamingo balance score and right and left reaction time of the athletics group. Regarding the total balance, sit and reach, reaction time score of athletics group, statistically significant differences were observed $(\mathrm{p}<0.05)$. Statistically significant decreasing were determined in respect of flamingo balance test scores was observed in the gymnastics group $(\mathrm{p}<0.05)$, there was no significant difference in reaction times $(p>0.05)$. There were no significant differences in pre-test and post-test of sit and reach test values in both groups.

Table 3 presents the scores of before and after physical activity training, there was an increase in muscle strength of quadriceps femoris muscle in athletic sports group ( $p$ $<0.05$ ), but there was no difference in quadriceps femoris muscle strength in the gymnastic sports group ( $\mathrm{p}>0.05)$. Back extensors and abdominal muscles strength values were not significantly different in both groups $(\mathrm{p}>0.05)$

Table 1. Mean age, weight, height and BMI of the groups

\begin{tabular}{cccc}
\hline Variables & $\begin{array}{c}\text { Athletics group } \\
(\mathrm{n}=30)\end{array}$ & $\begin{array}{c}\text { Gymnastics group } \\
(\mathrm{n}=30)\end{array}$ & $\mathrm{p}^{*}$ \\
\hline Age (years) & $12.83 \pm 1.64$ & $12.38 \pm 1.49$ & 0.627 \\
Weight $(\mathrm{kg})$ & $57.73 \pm 11.68$ & $49.09 \pm 8.59$ & $0.004^{*}$ \\
Height $(\mathrm{cm})$ & $153.36 \pm 12.21$ & $148.40 \pm 6.57$ & $0.018^{*}$ \\
BMI $\left(\mathrm{kg} / \mathrm{cm}^{2}\right)$ & $23.31 \pm 1.24$ & $18.13 \pm 4.98$ & $0.000^{*}$ \\
\hline
\end{tabular}

$*: \mathrm{p}<0.05$ shows the significance level according to the $\mathrm{t}$-test results of independent samples; the data are presented in mean \pm standard deviation

Table 2. Comparison of flamingo balance test, sit and reach test, reaction time values of the groups before and after the sport

\begin{tabular}{ccccccc}
\hline \multirow{2}{*}{ Variables } & \multicolumn{2}{c}{ Athletics group $(\mathrm{n}=30)$} & \multicolumn{2}{c}{ Gymnastics group $(\mathrm{n}=30)$} \\
\cline { 2 - 7 } & $\begin{array}{c}\text { Before } \\
\text { the sport }\end{array}$ & $\begin{array}{c}\text { After } \\
\text { the sport }\end{array}$ & p* & $\begin{array}{c}\text { Before } \\
\text { the sport }\end{array}$ & $\begin{array}{c}\text { After } \\
\text { the sport }\end{array}$ & p $^{*}$ \\
Flamingo balance test & $\mathbf{6 . 3 0} \pm \mathbf{3 . 0 8}$ & $\mathbf{4 . 5 0} \pm \mathbf{1 . 0 1}$ & $\mathbf{0 . 0 0 0 1 *}$ & $\mathbf{1 1 . 1 2} \pm \mathbf{2 . 4 9}$ & $\mathbf{8 . 8 5} \pm \mathbf{1 . 1 2}$ & $\mathbf{0 . 0 0 0 1 *}$ \\
Sit and reach test & $\mathbf{2 8 . 6 9 \pm 3 . 4 9}$ & $\mathbf{2 9 . 7 7 \pm 3 . 1 4}$ & $\mathbf{0 . 5 1 8}$ & $\mathbf{2 2 . 8 0} \pm \mathbf{1 . 4 8}$ & $\mathbf{2 3 . 0 1} \pm \mathbf{1 . 8 7}$ & $\mathbf{0 . 6 1 4}$ \\
Reaction time Right & $\mathbf{2 9 . 6 5} \pm \mathbf{2 . 5 0}$ & $\mathbf{2 2 . 1 4} \pm \mathbf{1 . 0 2}$ & $\mathbf{0 . 0 0 0 1 *}$ & $\mathbf{4 0 . 1 2} \pm \mathbf{3 . 5 3}$ & $\mathbf{4 1 . 0 2} \pm \mathbf{3 . 0 3}$ & $\mathbf{0 . 6 8 9}$ \\
Left & $\mathbf{3 0 . 0 0 \pm 3 . 6 7}$ & $\mathbf{2 6 . 1 2} \pm \mathbf{1 . 1 1}$ & $\mathbf{0 . 0 0 0 1 *}$ & $\mathbf{4 1 . 3 2} \pm \mathbf{3 . 1 8}$ & $\mathbf{4 2 . 2 2} \pm \mathbf{4 . 1 2}$ & $\mathbf{0 . 6 1 2}$ \\
\hline
\end{tabular}

*: $\mathrm{p}<0.05$ shows the significance level according to the t-test results of dependent samples; the data are presented in mean \pm standard deviation.

Table 3. Comparison of muscles strength of the groups before and after the sport

\begin{tabular}{|c|c|c|c|c|c|c|}
\hline \multirow[t]{2}{*}{ Variables } & \multicolumn{2}{|c|}{ Athletics group $(\mathrm{n}=30)$} & \multicolumn{4}{|c|}{ Gymnastics group $(n=30)$} \\
\hline & $\begin{array}{l}\text { Before } \\
\text { the sport }\end{array}$ & $\begin{array}{c}\text { After } \\
\text { the sport }\end{array}$ & $\mathbf{p}^{*}$ & $\begin{array}{l}\text { Before } \\
\text { the sport }\end{array}$ & $\begin{array}{c}\text { After } \\
\text { the sport }\end{array}$ & $\mathbf{p}^{*}$ \\
\hline $\begin{array}{c}\text { Quadriceps femoris } \\
\text { Right }\end{array}$ & $4.02 \pm 0.56$ & $4.56 \pm 0.32$ & $0.02 *$ & $3.02 \pm 0.35$ & $3.65 \pm 0.56$ & 0.101 \\
\hline Left & $3.56 \pm 0.78$ & $4.61 \pm 0.25$ & $0.0001 *$ & $3.15 \pm 0.10$ & $3.22 \pm 0.11$ & 0.231 \\
\hline Back extensors & $4.04 \pm 0.28$ & $4.21 \pm 0.56$ & 0.231 & $3.42 \pm 0.21$ & $3.50 \pm 0.14$ & 0.241 \\
\hline Abdominal muscles & $4.12 \pm 0.32$ & $4.25 \pm 0.46$ & 0.345 & $3.45 \pm 0.13$ & $3.68 \pm 0.25$ & 0.689 \\
\hline
\end{tabular}




\section{Discussion}

This study investigated the effect of doing gymnastic and athletic activity on balance, flexibility, reaction time, and quadriceps femoris, back extensors, and abdominal muscles strength parameters in children with hearing-impaired. This is the first study to compare the effect of doing athletic and gymnastic activity on balance, flexibility, reaction time and muscle strength of hearing-impaired children.

60 hearing-impaired individuals, aged between 12 and 14 years and engaged in athletic and gymnastic are included to study. When the demographic characteristics of the individuals were examined, there was not statistically significant differences were about their age, but there were significant differences between the groups in terms of height, weight and body mass index $(\mathrm{p}<0.05)$.

According to the results of Flamingo balance test, scores of the athletic group (before: 6.30 \pm 3.08 score, after: $4.50 \pm 1.01$ ), scores of gymnastic group (before: $11.12 \pm 2.49$, after: $8.85 \pm 1.12$ ) and the flamingo balance scores of the athletic group were lower $(\mathrm{p}<0.001)$.

In both groups, despite the positive developments in balance values after training, the balance development in the athletic sports group was better than the gymnastic sports group.

A study that was conducted with 15 hearing-impaired and 15 sedentary hearing-impaired individuals aged 16-19 who were actively engaged in sports by Kurt [13] reported that doing regular exercise resulted in improvements on the balance scale [13].

In a study, by Karakoc [11], stated that regular balance and coordination trainings have positive effects on performances of hearing-impaired athletes and also static and dynamic balance exercises are more effective on the performance [11].

Balance is an important factor for providing the body composition. It forms the basis of movement, specifically in dynamic sports involving sudden movements. Balance performance is required in all sport activities [8].

Rajendran V. [19] studied the effect of the exercise program on hearing impaired children, he found that the exercise program improved visual motor characteristics and eliminated deficiencies related to the vestibular system [19].

According to Carlson, age is considered to be an important factor in running, shooting, bouncing and climbing, in spite of causing the problem of balance in kicking the ball, jumping and bouncing [3].

A study that was conducted with healthy and hearing impaired children by Yağc1 reported that significant increase on balance ability in the healthy children group and was no significant change in the hearing impaired group. The study showed that being hearing-impaired affected negatively balance and movement system abilities [21].
When sports habits assessed, it has been observed that sporting activities are a positive effective on the development of physical performance and balance abilities. In many studies in the literature, reported that sporting habits, specifically vestibular coordination structures, improve their ability to work in harmony with each other [2, 17, 20.].

In calculating hearing reaction time scores of 51 hearing-impaired individuals and non-sports 105 hearing-impaired individuals were compared. As a result of the study, it was found that the active hearing-impaired individuals have shorter in reaction time than sedentary hearing-impaired individuals [9].

Ciğerci et al. [4] demonstrated the reaction times of hearing-impaired male volleyball players' right hands against light as $255.56 \pm 36.75 \mathrm{msn}$, reaction times of left hands against light as $244.90 \pm 27.82 \mathrm{msn}$ [4].

Çağlar et al. [5] measured the reaction times of hearing-impaired people as $341.20 \pm 53.24 \mathrm{msn}$ [5].

In this study, the reaction time was recorded in the athletic group as (right before: $29.65 \pm 2.50 \mathrm{ss}$, right after: $22.14 \pm 1.02$ ss, left before: $30.00 \pm 3.67$ ss, left after: $26.12 \pm 1.11 \mathrm{ss})$. The reaction time was recorded in gymnastic group as (right before: $40.12 \pm 3.53 \mathrm{ss}$, right after: $41.02 \pm 3.03$ ss,left before: $41.32 \pm 3.18$ ss, left after: $42.22 \pm 4.12)$. When the groups were assessed in terms of reaction time, it was found that the recorded times for the right and left lower extremities in the athletic group were shorter than the gymnastic group $(p<0.001)$ ( Table 2$)$.

In this study, the sit and reach test scores was recorded in the athletic group as (before: $28.69 \pm 3.49 \mathrm{~cm}$, after: $29.77 \pm 3.14 \mathrm{~cm}$ ), and in the gymnastic group as (before: $22.80 \pm 1.48 \mathrm{~cm}$, after: $23.01 \pm 1.87 \mathrm{~cm}$ ). There was no statistically significant difference in the flexibility values before and after training in both groups $(p>0.05)$.

In this study, the quadriceps muscle strength was recorded in the athletic group as (right before: $4.02 \pm 0.56$, right after: $4.56 \pm 0.32$, left before: $3.56 \pm 0.78$, left after: $4.61 \pm 0.25$ ), and in the gymnastic group as (right before: $3.02 \pm 0.35$, right after: $3.65 \pm 0.56$, left before: $3.15 \pm 0.10$, left after: $3.22 \pm 0.11)$. According to the evaluated result, a significant difference was observed in quadriceps muscle strength after training in the athletes $(\mathrm{p}<0.05)$, was observed no change in quadriceps muscle strength in the gymnasts $(\mathrm{p}>0.05)$. Values were no significantly difference was observed in terms of back extensors and abdominal muscles in both groups $(\mathrm{p}>0.05)$.

\section{Conclusions}

As a result of the work, the flamingo balance score and reaction times of hearing disabled individuals doing athletics were shorter and quadriceps muscle strength was more than individuals doing gymnastic. In addition, at the end of the training, the positive improving of these 
parameters has shown that athletic in hearing impaired develops balance, reaction time and muscle strength more than gymnastic. Hearing impaired individuals can be directed to the sport of athletics to increase daily living activity levels and quality of life.

\section{REFERENCES}

[1] Bayram D. (2003). Sanat, Spor ve Engelli Çocuk. Spor Araştırmaları Dergisi, Sayı 2, Haziran, s.3.

[2] Butterfield SA. (1991) "Influence of age, sex, hearing loss and balance on development of running by deaf children" Percept. Mot. Skills. 73(2): 624-6. (PMID: 1766796).

[3] Carlson B.R. (1972) "Assessment of Motor Ability of Selected Deaf Children in Kansas". Perceptual and Motor Skills, 34, 303-305.

[4] Ciğerci, A. E., Aksen, P., Cicioğlu, İ., \& Günay, M. (2011). 9-15 Yaş Grubu İşitme Engelli Ve İşitme Engelli Olmayan Öğrencilerin Bazı Fizyolojik Ve Motorik Özelliklerinin Değerlendirilmesi. Selçuk Üniversitesi Beden Eğitimi ve Spor Bilim Dergisi, (13), 35-42.

[5] Caglar, O., Uludag, A. H., Sepetc1, T., \& Calıskan, E. (2013). Evaluation of physical fitness parameters of hearing impaired adolescents who are active and non-active in sports. Turkish Journal of Sport and Exercise, 15(2), 38-44.

[6] Davis, A., Smith, P., Ferguson, M., Stephens, D., \& Gianopoulos, I. (2007). Acceptability, benefit and costs of early screening for hearing disability: a study of potential screening tests and models. Health Technology Assessment-Southampton-, 11(42).

[7] Demirel, N. (2018). The Impact of Therapeutic Recreational Gymnastic Exercise on Basic Motor Skills of Hearing-Impaired Children Aged Between 6 and 9 Years. Journal of Education and Training Studies, 6(3), 147-151.

[8] Eler, S., Yıldıran, İ., \& Sevim, Y. (1999). Bir Sezonluk Antrenman Periyotlaması Boyunca Üst Düzey Erkek Hentbolcuların Bazı Motorik Ve Fizyolojik Parametrelerinin İncelenmesi. Gazi Beden Eğitimi Ve Spor Bilimleri Dergisi, 4(3), 25-34.

[9] Eskicioğlu, Y. E., \& Çoknaz, H. (2016). Türkiye'de Futbol, Türk Halkoyunları, Basketbol Ve Voleybol Antrenmanlarına Katılan Ve Katılmayan İşitme Engelli Bireylerin Görsel Reaksiyon Sürelerinin Karşılaştırılması. İnönü Üniversitesi Beden Eğitimi ve Spor Bilimleri Dergisi,

$$
3(2), 18-25 \text {. }
$$

[10] Hazar, F., \& Taşmektepligil, Y. (2008). Puberte öncesi dönemde denge ve esnekliğin çeviklik üzerine etkilerinin incelenmesi. Spormetre Beden Eğitimi ve Spor Bilimleri Dergisi, 6(1), 9-12.

[11] Karakoç Ö. (2014) İşitme Engelli Judocularda Sekiz Haftalık Denge Ve Koordinasyon Antrenmanlarının Performans Üzerine Etkileri. Yayınlanmış Doktora Tezi., Sağlık Bilimleri Enstitüsü Beden Eğitimi ve Spor Anabilim Dalı, Frrat Üniversitesi.

[12] Kitiş A., Büker N., Eren K. E. \& Aydın H. (2015) "İşitme Engelli Kişilerde Statik Dengeyi Etkileyen Faktörlerin İncelenmesi” J Kartal TR, 26(1), 25-30 doi: 10.5505/jkartaltr.2015.06926

[13] Kurt A. (2007). Düzenli Egzersizin İşitme Engelli ve Normal Bireylerde Denge Parametreleri Üzerine Etkisi” Yayınlanmamış Yüksek Lisans Tezi. Erciyes Üniversitesi, Sağlık Bilimleri Enstitüsü, Beden Eğitimi ve Spor Anabilim Dal1. Kayseri.

[14] Otman S, Demirel H, Sade A (1998). Tedavi hareketlerinde temel değerlendirme prensipleri. Ankara: Sinem Ofset.

[15] Özer, D. S. (2001). Engelliler İçin Beden Eğitimi ve Spor. Nobel Yayın Dağıtım, Ankara.

[16] Özer, D.S., (2004). Engelliler için Beden Eğitimi ve Spor. Ankara: Nobel Yayın Dağıtım.

[17] Potter CN. (1984) "Silverman LN. Characteristics of vestibular function and static balance skills in deaf children" Phys. Ther.; 64(7): 1071-5. (PMID: 6739549)

[18] Rajendran, V., \& Roy, F. G. (2011). An overview of motor skill performance and balance in hearing impaired children. Italian journal of pediatrics, 37(1), 33.

[19] Rajendran, V., Roy, F. G., \& Jeevanantham, D. (2013). Effect of exercise intervention on vestibular related impairments in hearing-impaired children. Alexandria Journal of Medicine, 49(1), 7-12.

[20] Short FX. (1999) “McCubbin J, Frey G. Cardio respiratory Endurance and Body Composition. The Brockport Physical Fitness Training Guide, Ed. Winnick JP, Short FX, Human Kinetics"(ISBN: 0-7360-0120-4)

[21] Yağc1 N., Cavlak U. \& Şahin G. (2004) "İşitme engellilerde denge yeteneğinin incelenmesi üzerine bir çalıșma." KBB forum. Vol. 3.

[22] Zorba E. (2000) Fiziksel Uygunluk. Ankara: Neyir Matbaas1. 